\title{
Participation of Y Generation in 2018 General Elections
}

\author{
Dede Sri Kartini \\ Department of Government Science, Unpad \\ Sumedang, Indonesia \\ dedekartini@yahoo.com \\ Muradi \\ Department of Government Science, Unpad \\ Sumedang, Indonesia
}

\author{
Neneng Yani Yuningsih \\ Department of Government Science, Unpad \\ Sumedang, Indonesia
}

\begin{abstract}
Choose a candidate in general election is a part of public participation in its lowest level. Participation in election for Y Generation whom born on the 80's and 90's is predicted low, as depicted by the earlier generations. By using literature research, this essay will focus on understanding the characters of Y Generation, and several triggering factors to stimulate their participation. From previous research, these generations are known to have similar characteristics such as digitally literate persona, tend to neglect process and actively involved in social media. It is the time for the election committee and its participants took the advantage social media as a medium to deliver information which is related to election. Interesting information from social media will make those generation easy in deciding their vote for suitable candidates. Political parties, candidates and programs are determinant factors, and it should be well enough to attract their interest.
\end{abstract}

Keywords—Election, "Y” Generation, Voting

\section{INTRODUCTION}

General election is a medium for secure, peaceful and legitimate power succession. But as important medium in political structures, election is gradually being neglected by voters. It can be observed in Formappi data whom showed the decreasing numbers of voters, started form 1999 election until 2013. Of three legislative elections, the number of voters are decreased $92.99 \%$ in $1999,84.07 \%$ in 2004 and $70,99 \%$ in 2009. Meanwhile, the average participation in gubernatorial election in 11 provinces on $2012-2013$ is counted $68.82 \%{ }^{1}$

The declining participation trend from each election should be anticipated to prevent further degradation on future elections. Since low participation rates will affect the elections' legitimacy. The election administrator should pay attention into several aspects, such as: the quality of election, candidate, party and program or antipathy of voters in elections since election does not bring direct impact to improve their welfare. Whether the problem lies within the

${ }^{1}$ Voters Participation in General and Local Election. Accessed on Jan $26^{\text {th }} 2017$ at 11.09 a.m election participants (political parties and candidates), election organizers (KPU and Bawaslu) or the electorate itself, it is necessary to find and tackle solve low voting participation's problem.

\section{SCOPE OF QUESTION}

Based on the explanation above, this article will focus on observing various factors that affect $\mathrm{Y}$ generation to use their vote rightfully, not just choosing candidates randomly. But previously we would like to describe the reason behind why Y generation tend to have low participation rate in election. Thus, this paper is limited to the following issues:

a. Why do Y generations tend to have low participation rate in elections?

b. What factors do make Y generation become a cautious voter?

\section{DISCUSSION}

Election is a democratic medium to gain power for a ruler, and then after he/she has power, according to Jean Jeacques Rousseau, "Those who hold power must be able to turn force into right and obedience into obligation". The similar context happens in a democratic political system, it also seeks legitimation or legitimacy that allows them to gain submission and willingness from citizens.

"Legitimation is a key factor for political stabilization; as a source for resilience and successful aspect of a regime. In modern politics, various debates on legitimation are dominated by democratic issue. It becomes so dominant until "legitimized democracy" is often viewed as the solely form of meaningful legitimation." (Heywood, 2013: 137)

Legitimation can be achieved from election, to commemorate a person who rightfully has authorized power and demand his/her citizen to obey the ruler's policies. By this condition, election is a control mechanism from society to 
evaluate their ruler, whether they are eligible or not to be chosen.

Within democracy, everyone has a chance to determine their leaders in fair and secret mechanism. Democracy, beside promising "equality, justice, and freedom", it also becomes a value to combine and mediate various important problems which often contradicts each other (Held, 2006 : 306). Based on Held's statement, all matters should not be solved only for the sake of the state, but decision-making must rest on the interests of the people. For example, if the construction of a toll is located inside citizen's area, although toll development based on public interest, the government cannot take the area without suitable payment. The diversion of a person's rights should be ethical, starting from fixing the rate for land acquisition, and relocating the citizen appropriately. But Held do not hailing democracy, he only gives statement that democracy is not an at-ease solution to solve all problems.

Choosing candidates in election is one of the lowest levels of political participation, in addition to other political participation such as being an active member of a political party, interest group, political official, following a demonstration and so forth. This means, if at the lowest level itself cannot be followed properly by citizen, then what will happen with another political participation? We should prevent a condition when these two generations come to power; Indonesia lacks suitable citizens who like to engage in politics, both in quantity and quality terms.

\section{A. Participation Trends in Voting Candidates for $Y$ Generation}

$\mathrm{Y}$ generation is described by Manheim as a group of individuals which has similarities in age range, and embracing important historical events in the same period. By using periodical prediction from generation theory, $\mathrm{Y}$ generation has their own characteristic respectively.

Y generation which born between 1981-1994 are often called as millennial or millennium generation. $Y$ generation term is used by mainstream newspaper editor in U.S on August 1993. This generation uses many instant communication technologies such as email, SMS, instant messaging and social media such as Facebook and Twitter. Besides, online games is an amusement tools for this group.

The individual characteristics of the $\mathrm{Y}$ generation depend on economic strata, and familial background. They tend to have very open communication patterns compared to previous generations. As social media fanatic, their lives are heavily influenced by technological developments. They are also more open to political and economic views, and look very reactive to the environmental changes which are taking place around them. Besides, they are group who pay more attention to 'wealth', and at each stage of life will be different. At a young age, they will depend on teamwork. In adulthood will turn into people who will be more excited when working in groups, especially in critical moments. At middle-ages they will be very energetic, dare to make decisions and most able to be strong leaders. At the time they grow older, they will be a group of parents who are able to contribute and criticize the community.

Generations $\mathrm{Y}$ each have positive and negative traits. By understanding their differences, hopefully educators or political leaders can understand their traits according to their characteristics. They are technologically literate generation, which only distinguished by the number of elections that they had been followed. Generation $\mathrm{Y}$ has participated approximately 4 times the election.

Y genertaion are technologically literate generation, which only distinguished by the number of elections that they had been followed. They have participated approximately 4 times the election, has worked, Alt backdground education high school or university. Based on this ondition, it certainly has consequences on political participation.

All citizen is expected to participate in political environment to deliver information regarding to their needs and preference to the political decision maker (Hooghe, 2013: 341). As stated by Hooghe, elections became one of alternatives to deliver our preferences and political participation ended in two ways:

"First, political participation is an implemented action to express the voter's needs and demands. Whether the citizen is going to vote, participated in demonstration, or writing an e-mail to parliament member, it is obviously they have their own special preferences or demands and asking the political system to respond in certain ways. Second, they can give pressure to the decision maker to pay more attention in their demands. It is clearly observed in elections, which can be assumed if politician do not pay enough attention to those demands and preferences, it can be assured that they will not be elected again" (Hooghe, 2013: 341-343)

Political participation by using internet is a new phenomenon and create a change for voters to evaluate which politicians are eligible to be chosen. But unfortunately, this chance often being skipped by voters because of declining trends as described previously. The advance of technologies, apparently do not make voter easy to evaluate the politician whom compete in elections.

Again, political participation by using internet is a new phenomenon in political science, even though participation by using internet is included I conventional participation (legally participation, i.e. being actively involved in political parties) or non-conventional (illegal participation, such as joining demonstration) (Hooghe, 2013: 343). But according to current development, technology has embraced political environment such as e-campaign, or e-voting. Also, the advance of technology became the trademark of Y generation. It caused those Y generation become a digitally literate persona, but somehow, they became apathetical with their surrounding environment, such as election.

Generation $\mathrm{Y}$ who already have experience participating in election will tend to take evaluative manner towards candidate or political party. With their maturity, they will not randomly choose, but consider their vote based on easily accessed 
information. They do not simply accept processed information, but they will cross checked it with the other information. They will actively seek information, even willing to provide time to seek other information through mass media. In the brink of election day, the collected information will be more complete, so they dropped their vote based on their comprehensive reference. That is the ideal picture of $\mathrm{Y}$ generation in determining their choice in the election. From the characteristics of $\mathrm{Y}$ generations, the author tries to explain the factors that make people participate in election. Using a sociological, psychological and political economy approach in behavioral theory of choice, the author analyzes the two generations.

\section{B. The Voting Factors}

The first approach whom tried to evaluate voting behaviour in election s risen in Columbia University, so the approach is often called as the Columbia Scholl or sociological approach. Since sociological theory, precisely social character is used to analyse voting behaviour in this approach. The researchers from Columbia University explaining the 1940 election by using sociological models to find that socioeconomic status (education, income and class), religion and residence (rural or urban) are closely related to voter's choice and combined it into the "index of political predisposition" (IPP). For example, Protestants from rural areas with high socioeconomic status are more likely to vote for the Republican Party. Social group factors are being calculated and it will lead to different choices. But this model does not try to explain why many Protestants choose the Republic over Catholics. It means that this method do not calculated political aspects of the election. (Carmines and Huckfeldt, 1996: 228).

According to sociological approach, social characteristics determines political preferences. In here, the explanatory model is divided into models of microsociological and macrosociological explanations. The first model has always been associated with sociologists Paul F. Lazarsfeld, Bernard Berelson and Hazel Gaudet of Columbia University. While the second one is taken from Seymour Martin Lipset and Stein Rokkan who observed the election of Lazarsfeld's research. It examines voting behavior at all levels or layers in society as a whole that eventually led to an explanation of political parties systems in Western Europe (Roth, 2008: 23

Research using this approach will lead the researcher to the fact that a person with a particular religion will vote for party $\mathrm{X}$, for example an Islamic person will choose an Islamic party, religion becomes a factor influencing one's choice. The result of a person's choice is influenced by religion, so if other characteristics are being calculated, then the research will give an explanation of which variable possessed greatest influence and which variable is the least.

When Y generations are approached with this sociological approach, only candidates or political parties can campaign through social media only to be chosen, printed news will tend to be neglected, as these two generations use the Internet as a source of information. Thus, if this opinion is accepted, then the participation from several elections can be explained, i.e.: lack of election participants' information in social media. It can be easily tracked since the candidate website is using standard content, just contains mission vision, and do not explain a realistic program.

It is time for the election committee to make the website informative and attract more readers. Open campaigns that emphasize the current mass gathering have been reduced, this condition is appropriate for the characteristics of $\mathrm{Y}$ generations. Sociological factors such as education, employment, shelter, sex, religion is not applicable for $\mathrm{Y}$ generation. Personal character which becomes a barrier between individuals, cannot be done to distinguish this group. The only way to boost voter participation is using internet to provide information related to election, which is certainly in line with the interests of participants and election organizers.

The second approach comes from a Michigan University political scientist, which is called the Michigan approach or school or psychological approach, since it observes the things inside a person as the factors that influence their choice. These factors are identification political parties' identification, candidate and issue orientation.

According to this approach, voting is determined by three aspects: the attachment of a particular political party (party identification), the orientation of the candidate, and the orientation related to the political issues. Then, the three factors are known as the triage of determinants (Roth, 2008). They believe that choosing is an individual right. Political parties' identification is the basis for making choices. But the decision to choose "what candidates or which one" is determined by two factors: the parties' ability to formulate issues in the community, and how well the candidates' performance to deal with those issues. These two factors, according to Fiorina (1984) in Imawan (1993), can alter the direction of influence: from party identification to choosing pattern in determining political parties dentification.

If $\mathrm{Y}$ generation are approached with party identification, the authors assume only a few number of $Y$ generation whom already has party identification. Party identification is owned by people who are indeed sympathizers of the party at the lowest to the highest-level of loyalty. Only people who have loyalty or have been identified with their party alone will decide the choice based on political parties. Generation Y will determine their consideration based on the political parties' reputation, such as if the party is known clear from corruption.

Meanwhile, novice voters do not have experienced in party identification, in terms of age and social environment. There is a tendency that they will receive information from anyone as a reference to make choices. From this case, the participants and the election committee, should compete each other to inform the beginning voters, since the first information is usually embedded in the minds of beginner voters.

The choice of select voting can also be determined by the political parties' description in the eyes of committee, participants and voters. Differences perceptions which is varied between committee, participants and voters about political parties can lead to mutual problems when voter 
participant is low. All of them could be easily rejected what is perceived by the others.

\section{Table 1}

\section{Political Parties Description}

\begin{tabular}{|c|c|c|}
\hline $\begin{array}{l}\text { Political Parties' } \\
\text { Description as } \\
\text { View by KPUD }\end{array}$ & $\begin{array}{lr}\text { Political } & \text { Parties' } \\
\text { Description } & \text { as } \\
\text { View } & \text { by } \\
\text { Candidates } & \end{array}$ & $\begin{array}{l}\text { Political Parties' } \\
\text { Description as } \\
\text { View by Voters }\end{array}$ \\
\hline $\begin{array}{l}\text { 1.Political parties } \\
\text { are obeyed the } \\
\text { regulation } \\
\text { 2.Political parties } \\
\text { followed the } \\
\text { procedure } \\
\text { 3.Political parties } \\
\text { Works should be } \\
\text { in frame with } \\
\text { regulation } \\
\text { 4.Political parties } \\
\text { shoud be easy to } \\
\text { manage } \\
\text { demonstrate and } \\
\text { discipline attitude }\end{array}$ & $\begin{array}{l}\text { 1.Political parties } \\
\text { as political vehicle } \\
\text { 2.Political parties } \\
\text { is easy to be } \\
\text { bribed } \\
\text { 3.Political parties } \\
\text { are easy to control } \\
\text { 4. Political parties } \\
\text { could be arranged } \\
\text { according to } \\
\text { candidate interest }\end{array}$ & $\begin{array}{l}\text { 1.Politial parties } \\
\text { will nominate rich } \\
\text { candidate } \\
\text { 2.Political parties } \\
\text { will give material } \\
\text { incentives to voter } \\
\text { such as money, t- } \\
\text { shirt, etc } \\
\text { 3.Political parties } \\
\text { have hidden } \\
\text { motives } \\
\text { 4.Political parties } \\
\text { are a group of } \\
\text { pragmatist people }\end{array}$ \\
\hline
\end{tabular}

Source: Syahdan, Gregorius dan Haboddin. Muhtar. (2009: vi)

The second factor that determines the voter's choice according to the psychological approach is the candidate's orientation, which is often based on the candidate's background and track record. The candidate's ability to tackle negative issues against him will influence voters in making choices. If the voters are Y generations who are experienced in choosing and usually have an evaluation of candidates, then candidates who have a good track record and good at counteracting negative issues certainly will be selected by generation $\mathrm{Y}$. But the problem is: whether $\mathrm{Y}$ generation has easy access information, will it be easy to them to determine their choice from the available candidate? When the call to vote is a self-awareness of $\mathrm{Y}$ generation, the abstained vote number will be low. However, if, the problem is that the available candidate's offerings are not eligible to be elected based on Y generation standards, then it should be the subject of evaluation for voters.

The third factor is the program or issue which is performed by the candidates. It means meaning the vision of the mission submitted by the candidate who will become the vision of the mission for a certain area will determine the voter's choice. For Y generation, the candidates' program will be considered important, since they believe that the candidates' vision mission will derive public policy later. For that, candidates' programs will be compared, and Y generation's preference is based on whether the program is in line with their interest.
But, Y generation who became political party loyalists, certainly will not do that. For them, there is no better program except the program from their parties.

The final approach is a rational choice or political economy approach proposed by Anthony Down. This approach is emphasized on voter's rationality, which often called as the process in calculating profit and contrary side of the program proposed from candidates or political parties by their voter. The rational voter is the voter who calculates composition of pro and contrary side for himself against a program. They will seek, evaluate and then consider candidates' programs. After finding a program that suits their interests, and their choice are based from this consideration. For example, a teacher will select a candidate who continues teacher certification policy, because teacher certification is beneficial for them.

Rational voters tend to be selfish since their choosing methods only based on personal gain, not mutual benefit for the whole society. The voters who decide the election based on the program for majority benefit are the ideal voters who are expected to dominate election.

Rational voters can be chosen by $\mathrm{Y}$ generation who has consciousness to vote carefully. In accordance with the characteristics of the $\mathrm{Y}$ generation who have followed the election several times, and relatively has sufficient financial background, then the ability to search for information, selected, evaluate then choosing will be done consciously.

Rational voters can be chosen by $\mathrm{Y}$ generation who has consciousness to vote carefully. In accordance with the characteristics of the $\mathrm{Y}$ generation who have followed the election several times, and relatively has sufficient financial background, then the ability to search for information, selected, evaluate then choosing will be done consciouslyIn making decisions, ownership of information and knowledge are mandatory requirements, as Berelson (1972) has suggested, voters should be well informed of the rules of elections. Information is intended to enable voters to check which facts are right or wrong. Thus, voter can distinguish whose campaigns are correct according to the conditions of the candidate. Besides, possessed sufficient knowledge, is also useful when voters can are able to understand the quality of each candidate.

\section{CONCLUSION}

a. Low participation among $\mathrm{Y}$ generation in election can be traced from their characteristic respectively. Therefore, the election committee and participants should optimize the advantage of social media as a medium to deliver information which is related to election matters.

b. Conscience to find information throughout various media is a determinant factor from $\mathrm{Y}$ generation which able to transform them into cautious voter. Attractive information from social media will simplify their process in choosing candidates. Political parties, candidates, and programs are determinant factor. Thus they should be well presented by the candidates in order to optimize voters earning. 


\section{REFERENCES}

[1] Berelson, Bernard, "The Structure of Political Beliefs", in Heinz Eulau et als., (Eds), Political Behavior : a reader in theory and research. Macmillan Company, New York. 1972, pp. 107-115.

[2] Carmines, Edward G and Robert Huckfeldt, "Political Behavior : An Overview. In Robert E. Goodin dan Hans Dieter Klingemann (eds). A New Handbook of Political Science, New York : Oxford University Press Inc, 1996, pp. 223-244

[3] Imawan, Riswandha, "Analisis Hasil Pemilihan Umum 1992 di Indonesia", Laporan Penelitian, Yogyakarta : Universitas Gadjah Mada, 1993.

[4] Held, David, "Models of Democracy", Penerjemah: Abdul Haris. Jakarta : Akbar Tandjung Institute, 2007.

[5] Heywood, Andrew, "Politik", Penerjemah: Ahmad Lintang Lazuardi, Yogyakarta : Pustaka Pelajar, 2013.

[6] Hooghe, Marc, "Budaya Politik", in Ishiyama, John T and Breuning, Marijke (eds). Ilmu Politik : Dalam Paradigma Abad Ke-21 Sebuah Referensi Panduan Tematis, Penerjemah: Ahmad Fedyani Saefudin, Jakarta : Kencana Prenada Media Group, 2013.

[7] Roth, Dieter, "Studi Pemilu Empiris: Sumber, Teori-teori, Instrumen dan Metode" (Penterjemah : Denise Matindas), Jakarta : PT. Mitra Alembana Grafika, 2008.

[8] Syahdan, Gregorius dan Haboddin. Muhtar, "Evaluasi Kritis Pilkada Serentak". Yogyakarta : The Indonesian Power for Democracy (IPD), 2009.

\section{Website-based resources}

[1] Partisipasi Pemilih Pemilu dan Pilkada. (2017, January 26). from https: // www. Facebook.com Formappi /Post/434 44 494429976148.

[2] Pilkada Serentak di Jabar 2015, Golput Tertinggi. (2017, January 26). from http://www.pikiran-rakyat.com/politik/2016/08/01/pilkadaserentak-di-jabar-2015-golput-tertinggi-376268

[3] Gen-Y Alergi Politik ?. (2017, Januari 26) from http://www.republika.co.id/berita/koran/gen-i/16/05/24/o7oes81geny-alergi-politik 